\title{
Interleukin-1 receptor antagonist treatment revealed active hepatitis $B$ infection in a boy with PAPA syndrome
}

\author{
V Selmanovic ${ }^{1 *}$, F DeBenedeti ${ }^{2}$, A Omercahić-Dizdarevic ${ }^{1}$, E Kovac-Vidakovic ${ }^{3}$, S Mehanic ${ }^{4}$, A Cengic $^{1}$ \\ From 8th International Congress of Familial Mediterranean Fever and Systemic Autoinflammatory Diseases \\ Dresden, Germany. 30 September - 3 October 2015
}

\begin{abstract}
Background
PAPA syndrome (pyogenic sterile arthritis, pyoderma gangrenosum and acne) is a rare autosomal-dominant autoinflammatory disease caused by mutations in PSTPIP1gene. Typically presents with recurrent sterile, erosive arthritis in childhood, occurring spontaneously or after minor trauma, occasionally resulting in significant joint destruction. By puberty, joint symptoms tend to subside and cutaneous symptoms increase. Cutaneous manifestations include pathergy, frequently with abscesses at the sites of injections, severe cystic acne, and recurrent nonhealing sterile ulcers, often diagnosed as PG.
\end{abstract}

\section{Objective}

To report a case of hepatitis $B$ infection revealed with interleukin-1 receptor antagonist for PAPA syndrome.

\section{Patient and method}

$16,5 y$ boy with PAPA syndrome presenting at age 2 with pyogenic sterile arthritis requiring multiple surgeries (shoulders, elbows, knees, ankles, wrists). He was treated as JIA for 14y (NSAID, steroids (11 years, had growth retardation due to steroids), immunosupressants (metotrexate) and for short time biologicals (infliximab, adalimumab). Several years ago developed severe acne and nonhealing skin ulcers. In august 2013, the boy was referred to our Department and completely reevaluated. He had raised inflammatory markers, microcytic anaemia, normal transaminases. Skin biopsy: pyoderma gangrenosum. Kidney biopsy excluded amyloidosis. Started with adalimumab for 1 year. Joint disease was under control,

\footnotetext{
${ }^{1}$ Children's Hospital University Clinical Center Sarajevo, Department for Allergology, Rheumatology and Clinical Immunology, Sarajevo, Bosnia and Herzegovina

Full list of author information is available at the end of the article
}

but not skin disease. Clinical diagnosis of PAPA syndrome was confimed by genetic analysis in March 2014. He was heterozygous for the substitution $748 \mathrm{G}>\mathrm{C}$ in exon 11 that predicts the E250Q aminoacid substitution. When available, adalimumab was switched to anakinra in November 2014 (after washout period of 8 weeks). One month later, the patient showed raised transaminases (10 times above upper limit of normal). Active hepatitis B infection was proved by PCR. His mother had hepatitis B and boy had several surgeries with blood transfusions. How did he harbour the infection? Anakinra was stopped. On symptomatic therapy, transaminasemia soon normalised, but PAPA worsened. At present, he is on antiviral therapy and the issue if and when anakinra should be restarted.

\section{Conclusion}

We reported a boy with genetically confirmed PAPA syndrome. Treatment with adalimumab controlled joint but not skin disease. Interleukin-1 receptor antagonist was associated with activation of previously unknown hepatitis B infection, requiring antiviral therapy and withdrawal of treatment with anakinra. This case raises the question of the possible role of anakinra in activating the viral infection and the usefullness routine srceening for hepatitis B prior biological.

\section{Consent to publish}

Written informated consent for publication of their clinical details was obtained from the patient/parent/guardian/relative of the patient.

\section{Authors' details}

'Children's Hospital University Clinical Center Sarajevo, Department for Allergology, Rheumatology and Clinical Immunology, Sarajevo, Bosnia and Herzegovina. ${ }^{2}$ IRCCS Ospedale Pediatrico Bambino Gesù, Division of
() Biomed Central

(c) 2015 Selmanovic et al. This is an Open Access article distributed under the terms of the Creative Commons Attribution License (http://creativecommons.org/licenses/by/4.0), which permits unrestricted use, distribution, and reproduction in any medium, provided the original work is properly cited. The Creative Commons Public Domain Dedication waiver (http://creativecommons.org/ publicdomain/zero/1.0/) applies to the data made available in this article, unless otherwise stated. 
Rheumatology, Roma, Italy. ${ }^{3}$ Children's Hospital University Clinical Center Sarajevo, Department for Gastroenterology and Hepatology, Sarajevo, Bosnia And Herzegovina. ${ }^{4}$ University Clinical Center Sarajevo, Hospital for infectious diseases, Sarajevo, Bosnia And Herzegovina.

Published: 28 September 2015

\section{References}

1. Dierselhuis MP, Frenkel J, Wulfraat NM, Boelens JJ: Anakinra for Flares of Pyogenic arthritis in PAPA Syndrome. In Rheumatology. Volume 44. British Society for Rheumatology; 2005(3).

2. Brener M, Ruzicka T, Plewig G, Thomas P, Herzer P: Targeted treatment of pyoderma gangrenosum in PAPA (pyogenic arthritis, pyoderma gangrenosum and acne) syndrome with the recombinant human interleukin -1 receptor antagonist anakinra. British Journal of Dermatology 2009, 161:1199-1201.

3. Caorsi R, Insalaco A, Marotto D, Frenkel J, Martini A, De Benedetti F, Gattorno M: pediatric Rheumatology 2013, 11(2):P228.

4. Caorsi R, Federici S, Gattorno M: Biologic drugs and autoinflammatory syndromes. Autoimmunity Reviews 2012, 12:81-86.

5. Touitou I: Pyogenic artheritis - pyoderma gangrenosum - acne. Th portal for Rare disease and orphan drugs, october 2006., dostupno na : http:// orpha.net/consor/cgi-bin/OC_Exp.php?Lng=EN\&Expert=69126.

6. Demidowich AP, Freeman AF, Kuhns DB, Aksentijevich I, Gallin JI, Turner ML, Kastner DL, Holland SM: Genotype, phenotype and Clinical Course in Five Patients With PAPA Syndrome (pyogenic sterile arthritis, pyoderma gangrenosum and Acne). Arthritis 6 Rheumatism 2012, 64(6):2022-2027.

doi:10.1186/1546-0096-13-S1-P11

Cite this article as: Selmanovic et al.: Interleukin-1 receptor antagonist treatment revealed active hepatitis $B$ infection in a boy with PAPA syndrome. Pediatric Rheumatology 2015 13(Suppl 1):P11.

\section{Submit your next manuscript to BioMed Central} and take full advantage of:

- Convenient online submission

- Thorough peer review

- No space constraints or color figure charges

- Immediate publication on acceptance

- Inclusion in PubMed, CAS, Scopus and Google Scholar

- Research which is freely available for redistribution

Submit your manuscript at www.biomedcentral.com/submit
Biomed Central 